\title{
PRE-ROMAN DACIAN SOCIETY IN ROMANIAN HISTORIOGRAPHY
}

\begin{abstract}
This work aims to reconstruct the itinerary of the Romanian historiography that targets the Dacian society from the Dacian royal period. The study follows the evolutionary direction of the opinions regarding the indigenous society in Dacia and its stratification was followed. In the Romanian historiography, six periods are highlighted: the period of the first scientific historiography (the second half of the 19th century-1918), the interwar period(1919-1948), the Stalinist period(1948-1964), the period of the return to national values(1964-1975), the era of nationalist communism(1975-1989) and the climate of freedom after 1989. In an analytical and objective manner, the opinions outlined and stated by historians in each historiographic period are rendered. Great attention was paid to historical writing and to the conceptions set forth by historians regarding the stratification of the Dacian society, these being determined by the structure of the present.
\end{abstract}

Keywords: Romanian historiography, the Dacian society, pileati, comati.

\section{INTRODUCTION}

$\mathbf{W}$

hat does the Dacian society represent in the context of antiquity? How was it structured? What are the factors that determine the structure of a society? In Antiquity, was there a single model of society? Or there were multiple models of society? Can we catalog these societies similarly? Are there factors that differentiate between societies that are in similar developmental stages?

The present paper starts from these questions and tries to carry out a critical and objective analysis of the Romanian itinerary of the historical writing and the historiographical discourse concerning the Geto-Dacian society during the monarchy period. Romanian scientific historiography asserts itself since the end of the $19^{\text {th }}$ century and continues to make contributions even today.

In the study of the Dacian society and in the attempt to analyze and understand the mechanisms that make a society work, I have started with the unanimously accepted definition of society; so a society represents the whole group of people who enter into necessary and permanent relationships in order to survive. This human group has certain basic common features, which define and differentiate it from other societies present in the spatial and temporal coordinates.

The defining features and mechanisms that make society work are: territory, common language(s) (these must be in a harmonious relationship), common beliefs and customs, but there are other criteria (relatives, honor, citizenship, religion, etc.), resulting in the emergence of hierarchies of elites and subjects, which are necessary in a society ${ }^{1}$.

\section{Alexandra NICOLESCU}

Babeș-Bolyai University, ClujNapoca alexandranicolescu9718@gmail.com

DOI: $10.14795 /$ j.v7i1.523

ISSN 2360 - 266X

ISSN-L 2360 - 266X

\footnotetext{
${ }^{1}$ ALFÖLDY 1988, 5-10.
} 
Modern historiography has misinterpreted the Dacian society, a fact highlighted in the Romanian historiographical discourse. It is noted that during the first scientific works, which are written from the end of the 19th century, and during the interwar period, a nationalist view is outlined, but immediately after the establishment of the communist regime in Romania (1948) the official vision is that imposed by the ruling party, which looks at the Geto-Dacian society through the prism of "class struggle".

The historical writing of the communist period is influenced by the structure of the present, so that during the "communist era" there are several periods that are influenced by the changes that take place within the government. During the communist-nationalist period, the Ceausist ideology was imposed, which promoted concepts such as the "monolithic unity" and the "multimillennial continuity" of the Dacians, extolling the Dacian element at the expense of the Latin element, which is denied.

The month of December 1989 represents a liberation of the freedom of expression, also marking the end of a period in which the specialized and scientific works were drafted accordingto the wishes of the ruling party. Thishistorical moment marks the beginning of an era in which the research carried out in the Romanian space will be increasingly connected and linked with European research and historiography.

We remember that around 1900 the historians had as informational material only the literary sources, records in which the ancients transposed their own vision of the Dacians. The written sources convey to us what was known and believed at the time of immortalizing the information regarding the research topic. The situation changes since the ' 50 s because, since then, we have also benefited from continually increasing archeological, numismatic and epigraphic material; archaeologists are releasing the vestiges that attest to the existence of a stratified society during the period between Burebista and Decebal's reign.

In shaping the opinions regarding the Dacian society in pre-Roman Dacia, it is also necessary to include specialized works, from dictatorial times, in the canons of ideologies that oscillate according to the ruling party. But for periods of freedom, this feature depends on the ideological beliefs of each historian.

\section{THE BEGINNINGS OF SCIENTIFIC ROMANIAN HISTORIOGRAPHY \\ (SECOND HALF OF THE 19TH CENTURY-1918)}

The Geto-Dacian society reaches a high degree of civilization in the time interval between Burebista's reign and that of King Decebal. The development stage of this society also includes its stratification, but the appraisals regarding its depth vary, because the archaeological discoveries offer few relevant clues about this aspect, and the literary sources are not able to sufficiently clarify the details of this stratification.

In the 19th century there is a close connection between politics and historical writings, so that by the end of the 19th century the concept of critical school was born, causing a change in Romanian historiography through the perception of the historian as a professional, the sense of professional duty starting to differentiate itself from civic devotion. Under this sign, of positivist historiography, there are also the first scientifically argued references to the indigenous structure of pre-Roman Dacia.

At the end of the 19th century, not much was known about the Dacian society, the literary sources that speak of the Dacians are very few and quite deficient in terms detailing the society. Historians of the time have researched and analyzed these literary sources, on the basis of which they wrote books that deal with all or almost all the relevant aspects in order to better know our Dacian ancestry. Apart from the poor literary sources, historians also rely on the few images available - mainly those on Trajan's Column and the Adamclissi monument.

Historians living at the end of the 19th and early 20th centuries did not delve into all the relevant aspects of Dacian society; regarding the Dacian society they did not analyze the defining traits or the mechanisms that made it work, because the state of the information did not allow them to do so. The first opinions in this respect belong to Gr. Tocilescu, in his book "Dacia before the Romans", being the most representative work belonging to the last century, published in 1885, in which he thinks that within the society of Dacia there were two social classes: pileati, belonging to this were the nobles and priests, and capillati or comati, which made up the rest of the indigenous population of Dacia, and the element that made the distinction between the two classes consisted of the hat that was worn only by the nobles ${ }^{2}$. Grigore Tocilescu considers that only princes, priests and nobles had the right to wear the pileus, which is why they were called pilophors or pileati, while ordinary people were walking around with their bare heads and they were called comates or capillates ${ }^{3}$.

The national history synthesis written in 1888 by Al. D. Xenopol, also includes opinions on how the GetoDacian society was organized. We find out that the society was divided into two classes: in nobles and ordinary people, the former covered their heads with "a kind of tassel" named by the ancient writers as pileati, and the ordinary people were called comati or capillati and walked with empty head. Al. D. Xenopol tells the story of Dio Cassius, in which it is reported that during the first war between the Dacians and the Romans, Decebal sent Trajan a mission made up of ordinary people. When he saw that he could not yield the Roman emperor, he sent another message to him consisting of pileati. The story of Dio Cassius is evidenced by the figures of Trajan's Column, in which the first two heralds are depicted, the first ones are depicted without their heads covered, and above on the body of the column we can see the second heralds are depicted, whose members are represented carrying the pileuson his head ${ }^{5}$.

The subject of the Dacian society in the period of royalty is not of interest to historians writing during this period. The specialists deal superficially with this subject, only mentioning the existence of two social blankets in the pre-Roman Dacia. A decisive factor in shaping this view is the

\footnotetext{
TOCILESCU 1885,157

3 TOCILESCU 1885, 17.

${ }^{4}$ XENOPOL 1985, 106.

XENOPOL 1988, 108
} 
lack of archaeological material, so that a broad interpretation is not possible.

\section{INTERWAR PERIOD (1919-1948)}

In the time period between the two World Wars, a Romanian historiography is affirmed, which records a process of integration and compatibility with the great currents thatcrossed the 20thcentury ${ }^{6}$. In his firstworksNicolae Iorga remembers vaguely about the Geto-Dacian society and its stratification. In 1922, the historian refers to the society in Dacia with the following sentence: “... heralds to Dacians with empty or covered heads, comati and pileati are called, in the language of archaeologists"?

In 1926 the masterpiece of Vasile P, "Getica", a classic book of historical thought, a reference point from which no other archaeological thought can ignore, a starting point for new reconstructions and exegesis is printed. Vasile Pârvan notes in his work that, from a literary point of view, the separation of the Geto-Dacian society, in nobles and ordinary people, pileati and comati, is well known. This split of the Geto-Dacian society is also confirmed by monuments, especially by Trajan's Column, the nobles being differentiated represented by the ordinary people. The difference is that the nobles are represented wearing the characteristic soft, sharp cap, while the other Dacians are empty-headed.

Vasile Pârvan concludes that there is no difference between the clothing of the nobles and that of the king, the king differing nothing from the nobles in terms of clothing, which is why the historian draws a parallel between Dacia and Macedonia, where the king is called "primus inter pares". Also, the historian observed a similarity in the order of the Dacians from Bărăgan and Dobrogea, following the investigation carried out at the Adamclissi monument, where it is noted on the $45^{\text {th }}$ and $46^{\text {th }}$ metopes the noble prisoners are bound and transported separately from the ordinary prisoners ${ }^{8}$.

Later, in 1936, the first volume of synthesis, "History of Romanians", written by Nicolae Iorga, appears, a work in which the author outlines a particular opinion, thinking that Decebal seding a message to Emperor Traian using peasants is totally wrong, a sign of mockery against the Romanians, and that later his "chieftains" would appear?.

In a paper written in French and published in 1945, Constantin Daicoviciu noted that the Dacian society was divided into two major social classes: in pileati and capillati, considering that simple people led a different life from that of the nobles, but there was a unifying element represented by the common language and religion ${ }^{10}$.

Constantin C. Giurescu speaks in his synthesis of national history, reedited in 1946 , about a division of society in Dacia into two social classes: in nobles and ordinary people. The nobles of the Dacian society are mentioned in the literary sources as tarabostes and pileati, the historian considers that they were so named by the Romans because they wore on their heads the well-known wool or felt cap. The ordinary people werewalking with their heads uncovered

\footnotetext{
6 TEODOR 2002, 104.

${ }^{7}$ IORGA 1922, 47.

${ }^{8}$ PÂRVAN 1926, 147-149.

9 IORGA 1936, 143.

${ }^{10}$ DAICOVICIU 1945,71
}

and with their big hair, because of this they were called comati $^{11}$.

After uniting Romania, in 1924, the first archaeological campaign is being carried out at Grădiștea Muncelului, under the leadership of professor D. M. Teodorescu from Cluj, within the archaeological excavations there was focus on the research of the fortification wall and the round temple. With Constantin Daicoviciu taking over the excavations, the excavations expand considerably, archaeologists bringing to light most of the archaeological remains present in the Dacian complex. Also during this period, some investigations are carried out in Popești, led by Radu Vulpe, and in other places.

Also, in 1949, the archaeological excavations at Grădiștea Muncelului are directed and coordinated by the historian and archaeologist Constantin Daicoviciu, the discoveries that have brought to light some important problems of the history of our country and offer a novel vision about the society of pre-Roman Dacia.

The data collected after the archaeological excavations have not changed the existing opinions about the society and the structure of the indigenous population from preRoman Dacia, in the collective mind the same perception that existed before the war remains.

\section{STALINIST PERIOD (1948-1964)}

After the establishment of the communist regime in Romania (1948), a series of radical changes occurred, both economically and politically as well as socially and culturally. The establishment of the communist regime offers a new approach to history, one ideologically imposed, but the historiography of the communist decades is not a compact one, the changes at the center are also reflected in the way history was written, this being controlled and instrumentalized by the regime. The clearest expression of the new imposed order appears in Mihail Roller's history manual (1949), which exacerbated the "class struggle" and presented the Dacian society very schematically ${ }^{12}$.

The number of literary sources related to the GetoDacians and considered by historians has remained almost unchanged, but the number of archaeological researches carried out in Dacian settlements and fortresses has increased, contributing to a deeper and more detailed knowledge of the material and spiritual civilization of the Geto-Dacians.

In 1950, in a writing about the native civilization of the Orăștiei Mountains, Constantin Daicoviciu reminds of the existence of the division of the Dacian society in nobles/ tarabostes/pileati and ordinary people/comati/capillati, these being confirmed by the representations from Trajan's Column $^{13}$. The historian considers that by the term of comati/ capillati we have to understand not the totally free and rich peasants (they are rather part of the pileati), but that numerous class of the peasants without land, agricultural workers and miners, shepherds, craftsmen, who are in a state of dependence on the military nobility, they work alongside slaves on the lands and in the nobles courts. This social order

\footnotetext{
${ }^{11}$ GIURESCU 1946, 91

12 ROLLER 1948, 10-15.

13 DAICOVICIU 1950, 281.
} 
does not exempt the comati/capillati to bear the tasks of the war, as servants of the noble warriors. The war for food, for the acquisition of wealth, as one of the leading purposes of life, has become the permanent pursuit of warriors and nobles ${ }^{14}$.

The professor from Cluj draws a parallel between the plebeians from Rome and the ordinary people from Dacia, considering that there is a similarity between the two social classes. The historian sets out a new point of view, considering that in the 1 st century $\mathrm{BC}$ there was already a social blanket, that of the merchants, which dealt only with the exchange of products. At the base of these statements are the discoveries of monetary treasures, buried especially in the middle and end of the first century, which admits the constitution of such a social blanket from this century ${ }^{15}$.

Next, Constantin Daicoviciu talks about the existence of slaves in the Geto-Dacian society, and to support this point of view, it is based on literary and archaeological sources. He considers that the erection of the fortifications in the Orăștiei Mountains could not be carried out in time and space without the forced labor of thousands of people, with numerous animals and tools, so without the work of servants and a class of servants subjected to their masters. The historian is of the opinion that the sporadic emergence of slaves/slaves from prisoners of war is a social phenomenon that counts back several hundreds of years, and their proliferation and increasing economic importance in the hands of society's leaders seems to him a well-known fact for the period of the Dacian fortresses. The existence of slaves in society if they consider it confirmed by some literary sources, such as Plinius's letter to Emperor Trajan and the writings of Dio Cassius ${ }^{16}$. Therefore, the historian considers the Dacian state as a "beginner slave".

This opinion somewhat made the archaeological information agree with the commands of marxist ideology, in an acceptable form, which came to be imposed.

Between 1960-1964, the work "History of Romania" represented the turning point for a hybrid historiographical discourse, of a marxist-leninist type and slightly nationalist at the same time. Being published in a period marked by reassessments, hesitations, uncertainties, reversals and contradictions, the paper is the first and only academic synthesis of national history published during the communist regime in Romania. Equally, it is one of the official historiographic works, relatively moderate both in terms of marxist-leninist and nationalist excesses.

The official vision, framed in the first volume of the "History of Romania", on the society in pre-Roman Dacia will also be established by Constantin Daicoviciu. Thus, according to the typical marxist schemes, all the changes in the production forces "necessarily" lead to the modification of the production relations and the transformation of the Dacian society. The placeof the gentile community (where it was about the commonownership and equal distribution of the obtained goods) is taken by the village (neighborhood) which, although it knows, mainly and legally, a common property of its members on the land, water, pastures, leaves free space for private property. Social differentiation leads

\footnotetext{
${ }^{14}$ DAICOVICIU 1950, 34.

${ }^{15}$ DAICOVICIU 1950, 282.

${ }_{16}$ DAICOVICIU 1950, 33.
}

to the appearance of exploiting minorities, of the noble owners of large plots of land, of cattle, riches in precious metal, and of a majority exploited. The mode of argument presents internal contradictions: thus, the slaves are the most exploited class, but the slavery is not of the "classical" type, but patriarchal (work in mines, in public works, in the court of the king), however, the vast majority of production would be provided by peasants and free craftsmen or in a state of dependence on the nobility ${ }^{17}$.

Of the two social classes mentioned in the sources, comati/capillati would not represent the free peasants, but would be a social class similar to the plebeians in Rome. Thus, the Dacian state can be labeled as a beginner-military slave state. It is so called because, even though the slave relations were still little developed during the time of Burebista and his descendants, they represented the new element, capable of development and in continuous development. It is called a beginner slave state because in this state there can still be no generalization of slave production relations or the transformation of slave labor based on social production ${ }^{18}$.

During this historiographic period archaeological researches carried out in Dacian settlements and fortifications bring to light a multitude of archaeological material, but a correct and evolutionary interpretation cannot be achieved in asserting opinions on the Dacian society during the period of royalty due to the fact that the communist regime imposed a certain vision, regarding the Dacian society and state as one sourced in slavery.

\section{RETURNING TO NATIONAL VALUES (1964-1975)}

The historiographic evolution of this period was determined by the events that took place in the political sphere and there is a distance from the Soviet policy and the opening of national roads. During this period, contacts with the West increased, resuming some traditional abandoned subjects, historians gradually approaching the values in circulation in the free world. In this environment, the Romanian historiography records a process of reconnection to the universal historical course, but at this time politics still intervenes, but rather on the contrary, it becomes an increasingly efficient one ${ }^{19}$.

The opinions of historians are "emancipating", becoming more and more widespread, as a result of an increasing number of excavations and researches carried out in Dacian cities and settlements, but the negative element, which prevents an evolution in giving an opinion on the Dacian society and the way in which stratification was performed, it is the constraint of a certain vision.

The notion that in the Dacian society there were two social classes is almost universally accepted, but this opinion develops, giving the idea that the Dacian society is characterized by the fierce struggle between the social classes.

The first volume of the work "From the History of Tranylvania" (the concept expressed in this volume belongs to Constantin Daicoviciu), published in 1963, brings to our attention the division of the indigenous population in Dacia: in nobles-tarabostes and ordinary people-comati, the

\footnotetext{
${ }^{7}$ HISTORY OF ROMANIA 1960, 280.

${ }^{18}$ HISTORY OF ROMANIA 1960, 282-284.

${ }^{19}$ TEODOR 2002, 124.
} 
idea highlighted in this work is based on both literary and epigraphic sources and archaeological research. The ancients vaguely recall the existence of slaves in the Dacian world, the slavery in Dacia retaining a patriarchal character, the slaves being used in the field work (on the fields of the king and the nobles) and in the domestic work. One cannot speak of a generalization of slave production, but of a beginning of it with the tendency towards the true slave system ${ }^{20}$.

The same literary sources and archaeological sources speak of the existence, within the Geto-Dacian society, of rulers who belonged to the noble class and had positions within the army or were positioned at the forefront of agriculture. These, like the multitude of fortresses and watchtowers, are an indication that we are no longer dealing with any institutions of the people, but rather with the rulers of a central power, of a state that has a permanent army.

In 1965, the paper "Dacii", written by the historian Hadrian Daicoviciu, appeared, which in addition to dealing with topics related to the general history of the Dacians, speaks also about the Dacian society, about how social differentiation appeared and about the modalities of "exploitation". The historian thinks that within the village, the land of the community was divided periodically between the different families, but over time this concern for the equality of the members of the tribe disappears, the tillable land being privatized and owned by the wealthy families. The war represented, together with the development of the monetary exchange, a means of enriching the nobility class, which eventually transformed from a category of leading among equals into a real exploitative class ${ }^{21}$.

According to the historian, the nobility comes into possession of the entire political and military power, within this social class the king/chief was chosen, who as he consolidates his authority begins to have the pretense of transmitting the power to his descendants. And through the archaeological digs we get to know the rich houses and tombs of the nobles and the poor houses of the ordinary people. Professor Radu Vulpe discovered, within the excavations of Popești, a housing complex that formed the "court" of the local tribal chief ${ }^{22}$.

Within the site the constructions were made of wood and clay and had a rustic appearance, but compared to other dwellings discovered in this settlement, they formed a real palace, whose inventory only confirms the high rank and wealth of the owner. Ancient literarysources talk about the existence of slaves in the Daciasociety andtheir exploitation by the noble class. Hadrian Daicoviciu states that in Decebal's Dacia there was no internal market for slaves, and most of the slaves belonged to the state, in support of this opinion comes the fact that when Emperor Trajan conquered Dacia he found the prisoners taken in the war with Domitian, in one of the Dacian fortresses in the Orăștiei Mountains ${ }^{23}$.

Along with the old patriarchal exploitation of slaves, there is also the exploitation of poor by the wealthy, as a result of the differentiation of wealth that settles between the social classes in Dacia.

\footnotetext{
${ }^{20}$ FROM THE HISTORY OF TRANSYLVANIA 1963, 27.

${ }^{21}$ DAICOVICIU 1965, 81-82.

${ }^{22}$ DAICOVICIU $1965,83-85$

${ }^{23}$ DAICOVICIU 1965, 210.
}

These ideas are written successively and are specific to the specialized works of that period. In the work of the "History of Romania", the compendium from 1969, in addition to the conceptions about the generalization of private property, the deepening of wealth differences, the servitude of ordinary people and the seizure of military and political power by the leaders of the society, is also noted about the role that the priesthood plays in the Dacian society. There is talk of the hierarchical organization of the clergy, who had a pontiff at the forefront, who was also an adviser and an influential person beside the king ${ }^{24}$.

Starting with the years ' 68 - '70 of the last century, there is a detachment and differentiation between the communist ideology and the historical writing. The one who approaches a new perspective and to some extent combats previous opinions is Hadrian Daicoviciu. In 1972, the work of "Dacii" was reedited, which originally appeared in 1965, and within the new edition the historian of Cluj rectifies the "mistakes" pronounced previously ${ }^{25}$.

Regarding the Dacian society during the period of royalty, ideas were issued that addressed the same problems previously treated, but now the problem of "class struggle" is treated differently, daring to assert ideas that were not completely aligned with the communist ideology.

The historian points out that about 20 years ago, marxist-leninist historiography did not allow the division of the concepts of "ancient state" and "slave state", thus giving rise to the formula of "beginner slave state" and was applied to the political formation led by to Burebista. By analyzing the term "beginner" we want to emphasize that in pre-Roman Dacia slaves were not the basis of social productions and were not the main suppliers of material goods. Within the indigenous society of Dacia the slaves were not the predominant element, but the slave relations marked the new element, capable of evolution and in a stage of development ${ }^{26}$.

The slaves are assigned a very limited role in the production, the specialists are unanimous in supporting this opinion and as an argument they use the writings of Dio Cassius, who notes that after conquering Dacia, Emperor Trajan found the prisoners taken by Decebal in the war with Domitian in one of the Dacian cities. This passage shows that there wasn't a marketfor slave trade in the Dacian state, and most likely they became a kindof state property, of the king and forced to work on the Sarmizegetusa construction ${ }^{27}$.

Hadrian Daicoviciu notes that the last phase of construction, from Grădiștei Hill, which can be dated to the 1st century $\mathrm{AD}$ and in the first years of the next century, was not completed at one of the andesite sanctuaries until Emperor Trajan conquered the Dacian kingdom, so the above reasoning regarding the non-existence of a slave market in Dacia is fair, which means that even during Decebal's reign, slavery was not developed, or more developed than it was in Burebista's time. In this work, notes are made about the importance of the priesthood in the leadership of the Dacian state during Burebista's time, Strabo depicting the high priest Deceneu as the king's chief advisor. Iordanes writes

\footnotetext{
${ }^{24}$ HISTORY OF ROMANIA 1969, 42.

25 DAICOVICIU 1972, 119

26 DAICOVICIU1972, 157

${ }^{27}$ DAICOVICIU 1972, 159
} 
about the fact that he was vested with the supreme power, holding the position of viceroy, and of major importance is that after the death of Burebista, the one who follows them to the throne of the Dacian state is precisely Deceneu ${ }^{28}$.

In another paper also published in 1972, Hadrian Daicoviciu mentions that the problem of the Dacian state is a particularly difficult one, due to the lack of literary and archaeological information, but also because the ancient historians have been unsatisfactory about the economic and social issues. The archaeological discoveries, even if they attest to the existence of two social classes in pre-Roman Dacia and highlight differences in social status and wealth (archaeological digs bring to light palaces and cottages, rich tombs and poor tombs, inventories that include objects of luxury and inventories that are reduced to the strict necessities of life), are not in a position to talk about the concrete form of exploitation and to enrich our knowledge regarding the structure of the Dacian society of the Burebista - Decebal period.

The historian notes that for the period of the Dacia kingdom from the literary sources we obtain little and insufficient information about the structure of the society, the literary sources only informing us that the Dacian society was divided into two main classes: the aristocracy/ tarabostes/pileati and the common people/comati/capillati. Also on the path of literary sources we find that within the society of the Burebista-Decebal era there were slaves and freedmen, but regarding the number and role they played in production we can only speculate, this situation is repeated in the case of social classes and the form of subordination and exploitation of the common people by aristocrats ${ }^{29}$.

D. M. Pippidi shares the same opinion as Hadrian Daicoviciu and refuses to attribute to the slave labor as significant a share in the social production to the Dacians and takes into account that in the Dacian society the main productive category was made up of free noble people/comati, ploughmen and craftsmen ${ }^{30}$. But it is difficult to establish the concrete form of their exploitation by the nobles, the historian of Bucharest considers that the aristocracy most likely took advantage of some inherited ordinances from the primitive commune (benefits on thepublic land, for the king, for temples, etc.), with the possibility that a land lease system or a clientele system to be maintained ${ }^{31}$.

On the issue of the social structure of the GetoDacians, Hadrian Daicoviciu admits for the first time the existence of an "asian way of production" 32 . Following the analysis of the classical slave states (Pericle's Athen, Gracchi brothers Rome) and the eastern state formations, it should be emphasized that the latter, which can attest to a millennial existence, never reach advanced slavery (an example is his Ptolemic Egypt, where slave relations have a lower share in the economy compared to the classical slave states) ${ }^{33}$.

Therefore the historian Hadrian Daicoviciu notes that it is not necessary for an ancient state to develop

\footnotetext{
${ }^{28}$ DAICOVICIU 1972, 160-163

${ }^{29}$ DAICOVICIU 1972, 80.

${ }^{30}$ PIPPIDI 1967, 519, 523.

${ }^{31}$ DAICOVICIU 1972, 83.

32 Also called tributary mode.

${ }^{33}$ DAICOVICIU 1972, 161.
}

economically and socially in a direction of generalizing and stabilizing slave relations, because antiquity knows other forms of exploitation.

In the case of the state, if the unanimously accepted opinion is that in the production of pre-Roman Dacia, the slaves did not play a major role, the historian being of the opinion that the huge complex in the Sarmizegetusa area, which testifies about the existence of a state-type organization, is not a clear proof of the use of servile labor.

Hadrian Daicoviciu treats this problem with justifiable caution, leaving in the light of future research the task of delimiting the state founded by Burebista both in relation to the classical slave states and to the state formations of the Ancient East.

In a synthesis published in 1974 Mircea Babes analyzes the outlined conception in the specialized and pertinent works of the historian Hadrian Daicoviciu. Even though around the '65s, Hadrian Daicoviciu, defined the Dacian state as a "beginner slave state", the historian's opinion changes, and in future works he talks about a state where "the work of people and not of slaves was the main source of material good". Mircea Babes notes that a first statement of the fact that slaves do not play an important role in the social-economic life is made by D.M. Pippidi, in 1958. The idea that free people and not slaves represented the Dacians main production force gradually gained ground, this fact also reflected in the treaty of the History of Romania, written in $1960^{34}$.

In order to define the categories and relationships existing within the indigenous society in pre-Roman Dacia, Mircea Babes refers to the work of Miron Constantinescu, a marxist ideologist, who considers that the state does not appear in the tax system, and the possibility of the state being only at a certain stage. It also specifies the existence of two main phases in the evolution of the tax system: a first phase is represented by the inter-community organization of society, which has not reached a state level, and the second phase is the development of productive forces, by organization of production, development of social classes and organization of society, which requires the emergence of the state ${ }^{35}$.

The establishment of the operating relations, the appearance of the classes and the state organization have a procedural character, which extend over several centuries and it is emphasized that during the 1 st centuriesBC-AD, Geto-Dacians have passed the military democracy stage, but without forming a typically "asian" society or a "trbibutary" one. Mircea Babes explains the predominantly religious character of the monuments in the Orăștiei Mountains by analogy with the existence in society if of a social category that held religious functions. He considers that on the eve of the Roman conquest, the society in Dacia was not permanently divided into antagonistic classes and had not reached the level of a complete and stable state organization ${ }^{36}$.

In 1974-1975 he appears in the Yearbook of the History Museum in Deva, Sargetia, an article written by Mircea Valea and Anghel Nistor, a paper that analyzes the society in Dacia and the way in which certain historians have perceived it in

\footnotetext{
${ }^{34}$ BABES 1974, 238.

${ }^{35}$ CONSTANTINESCU1972, 6.

${ }^{36}$ BABEȘ 1974, 241.
} 
different periods. The stratification of the Geto-Dacian society in the 1st centuries $\mathrm{BC}-\mathrm{AD}$ is demonstrated by the names of some social categories existing in the Geto-Dacians and mentioned in ancient sources. According to the stories of the ancients, the nobility class in Dacia was called, in their own language, tarabostes, while the Latin-language sources use the term pileati, and the Greeks call them pilofori, and as a distinguishing sign, of the special rank they have in society, they wore that pileus (a cap similar to the Phrygian cap) ${ }^{37}$.

If we admit that in the language of the Dacians the name given to the nobility was not related to certain distinctive traits (wearing the pileus), then it can be admitted that another term, cometai, which is used by ancient sources, may have social significance and refers to the period of Decebal. Tacitus makes mention of the existence of a social institution in the Germans of the 1st century $\mathrm{AD}$, comitatus, an assembly in which the members were called comites (the term is Latin and defines the companions of the military chief). Samuel Noah Kramer makes specifies about certain common features that are encountered in antiquity in several peoples: Sumerians, Greeks, Germans, Indians, who, though distanced in time and space, are organized into tiny kingdoms, and each of the kings of these peoples were backed by a comitatus - a group of armed partisans who blindly obeyed him ${ }^{38}$.

Starting from these premises, the two historians consider that this group called comitatus also existed in Dacia, during the period when the sources refer to this term. Probably the word cometai is an indigenous Dacian word, having the same Indo-European radical com-, as the term comitatus. It is probable that the Greco-Romans or the modern historians approached the word cometai with the term that was known to them, namely coma, with the possibility that this term would have been modified following the transcription. The ancient writers who refer to the term cometai are Dio Cassius and Petrus Patricius. The latter mentioned above speaks of the messages that Decebal sent to Emperor Trajan, pointing out that the latter message was carrying pileus- because they are considered to be "more visible" Dacians, and those who formed the first deputation, cometai, were consider "ordinary people". The historians consider that the opinions according to which, Decebal, considering the extremely precarious situation in which he was, were erroneous; would he be allowed to send to the emperor Traian a message using ordinary people, as a sign of contempt for the Romans ${ }^{39}$.

This view was not imposed on historiography. In fact, both authors were not specialists in ancient Dacia research. But the idea will be resumed, with a broader argument, by I. H. Crișan in the next period. It should be remembered that this resumption was not a convincing one.

\section{NATIONALIST COMMUNISM (1975-1989)}

During this period, history became a real Instrumentum Regni, which was meant to legitimize the politics of the communist state, through the particularization and singularization of Romanian history. It is a communist

\footnotetext{
37 VALEA/NISTOR 1974 -1975, 1

${ }^{38}$ KRAMER 1962, 264-265.

${ }^{39}$ VALEA/NISTOR 1974-1975, 2.
}

state more and more oriented towards isolationism and the exacerbation of the national specific - different than that during the Stalinist period, and from this moment we witness an escalation of Dacism and an implicit and explicit denial of the Roman element.

In this decade we note that an offense was brought against the Romanian Academy, which was practically non-existent, the Central Committee of the Romanian Communist Party was entrusted with the coordination of research and education. During this time, historians have continued to write history, some of them committed to materializing the expected ideas of power, but most and most valuable people have continued to remain faithful to certain scientific conceptions and themes ${ }^{40}$.

Ion Horațiu Crișan, a prominent personality from Cluj, a valuable researcher and prestigious archaeologist, published a paper in 1977 through which he analyzes how the Dacian society was stratified, at the same time drawing a parallel between the Dacia society and the Celtic society. In his research he draws on the literary sources from the ancients, Dio Cassius and Dion Chrysostomos, and as a result of studying the literary work of the latter states that in Dacia there were two social classes. The natives were called, at an early stage, tarabostes, then for the period of the DacianRoman wars during Decebal's time, they are mentioned by Dio Cassius under the name of pileati and within this social class kings and priests were chosen ${ }^{41}$.

The ancient historian informs us that during the period of Burebista the nobility class was named in the Latin sources as pileati, due to the fact that they had as a distinct sign, the famous pileus, but long before they were called tarabostes. The conclusion we reach is that, within the society of Dacia, the nobility had appeared for a long time. Along with the nobility, capillati/comati are also mentioned, being mentioned in two of the ancient writings. Iordanes mentions in his work that the high priest Deceneu chose among the pileati the most important and wise men and taught them the mysteries of theology; the old man also says that Deceneu ordered "the rest of the people to be called capillati ...." The second clarification regarding the capillati is made by Dio Cassius, who tells that during the war between the Romans and the Dacians, Decebal sent to the emperor Trajan a messager which was one of the best pileati, not as before from among the capillati. I. H. Crișan insists that it is inadmissible that Decebal's messager to Emperor Trajan, in order to mediate peace, be made up of ordinary people, coming from the slave and exploited mass, who in some cases face a situation similar to slaves ${ }^{42}$.

The historian makes a comparison between the Celts and the Dacians, considering that the way of structuring the social classes and the stratification known to the Celts can also be applied to the Dacians. He thinks that if the nobility class in Dacia, represented by the pileati, corresponds to the aristocracy present in the Celtic and Roman world, then comati constitute the knights (equites), existing in both the Celtic and Roman worlds, so a blanket of warriors near the nobility, a lower-class social elite.

\footnotetext{
${ }^{40}$ TEODOR 2002, 126-127.

${ }^{41}$ CRIȘAN 1977, 195

${ }^{42}$ CRIȘAN 1977, 195-196.
} 
He also considers that the Geto-Dacian priesthood is hierarchized, possessing a special influence in the course of the whole life, the high priest being at the same time a viceroy, this power being entrusted for the first time by Burebista. The high ranks of priesthood were recruited from the ranks of the great nobility, pileati, and the mass was represented by capillati. For the time of Burebista the existence of numerous archaeological and literary evidences determined Ion Horațiu Crișan to support the existence of a rich and stratified nobility, from among the pileati and the existence of an exploitative class - classes to which the mass of ordinary people was part of, represented by comati/ capillati. The historian thinks that within the pre-Roman Dacia society there was a deep stratification, dividing into rich and poor, the rich constituting the exploiting class ${ }^{43}$.

The scholar is of the opinion that the Dacian state does not have a slave character and refuses to assign slaves an important role in social production, concluding that there must have been a state formation of another type, other than the slave one, which was able to ensure the development production forces and social relations, so it is in favor of a social formation that has been called by historians "asian/tributary". The distinction between the "asian/tribal" social formation and "the primitive commune" or "the slave formation" consists in the fact that the connections between the members of the public are no longer based on blood links, but on the economic requirements of the neighborhood ${ }^{44}$.

In 1980, Dumitru Berciu published an article analyzing the Dacian society during Burebista's reign. Following the analysis carried out on the archaeological and numismatic researches and by studying the few literary sources, it can be stated that the Dacian society around Burebista's reign was divided into two social categories: nobles/tarabostes (in the Thracian-Geto language ${ }^{45}$ ) among whom the kings and priests were chosen and the free people represented by the capillati/comati ${ }^{46}$. The historiographical conception, contemporary with the historian, admits that the society in pre-Roman Dacia did not develop under the conditions of a slave system, the state during Burebista and Decebal's reign was not a slave state.

For the period of Burebista's reign, the historian speaks of the existence of an indigenous society, structured in a unitary way, which constituted a well-connected entity and due to the existence of this unitary society Dumitru Berciu explains the victories gained by Burebista and his long reign. It also notes the existence of the priests in the Geto-Dacians, who in addition to the religious function also exercised a legal and political function, being elected from the heads of the nobility.

The ideas of both historians agree at least in asserting an ancestral unity and a deeply original civilization in the Dacians, which is why these ideas were approved by the Ceausist regime.

The work collaborated by historians Nicolae Gostar and Vasile Lica, published in 1984, aims to address the important issues regarding the Geto-Dacian society: the

\footnotetext{
${ }^{43}$ CRIȘAN 1977, 198

${ }^{44}$ CRISSAN 1977, 209.

${ }^{45}$ RUSSU 1967, 124.

${ }^{46}$ BERCIU 1980, 138
}

structure of the society and the political organization, the royalty, the aristocracy, the priesthood, the class of the counties, the slavery aspects and property. This work is the first scientific research dedicated entirely to the analysis of these problems, which are studied extensively by interpreting the archaeological material and literary sources. The issues that will be discussed in the present work have been analyzed previously by historians of different historiographical periods.

A large proportion of the writing is dedicated to certain topics that refer to and have significance for the Dacian society. In the beginning the political historical elements are presented, illustrating the general framework in which the Dacian society developed during the time period between Burebista and Decebal's reign. The paper focuses on studying the relevant elements in defining the Dacian society, so that the authors note that those who were called tarabostes/pileati represented the aristocratic class, which benefited from a great authority in the state. This influence held by the aristocracy is due to the fact that the nobles were those who sat around the king either in royal advice, or in his name, ruled the great cities or dealt with administrative problems ${ }^{47}$.

The prestige and authority of the noble class (which was based both on the noble origin and the possession of an economic power) is affirmed as a result of the recruitment of the clergy from its ranks (we refer to the high priest Deceneu, to whom the ancients attribute the carrying out of a religious reform), but also due to the fact that they are military commanders, members of the elite troops, a fact also highlighted on Trajan's column ${ }^{48}$.

Ancient texts and archaeological research reveal a side of the priesthood in Dacia, the Dacian priests being portrayed as keepers and creators of culture. By the term of comati the two authors understand the common people, an opinion issued in accordance with the whole historiography, but they also take into account the other opinion existing in the Romanian historiographic discourse. The historians note that the one who holds a different opinion and challenges the one existing in the historical writing is I. H. Crișan. In his first monograph in 1977, he states that comati would be a privileged category. In support of these arguments, the historian refers to Caesar's work, which describes the Celtic society, the historian realizing a comparison between the two societies. Lica and Gostar consider that this social category cannot be classified as belonging to the nobility ${ }^{49}$.

The literary sources speak about the existence of slaves in pre-Roman Dacia, and the authors mentioned above consider that slaves did not play a major role in the economy of the Dacian society, the dominant position being held by the comati that were providing different services to the state, the king and the nobility.

In the research carried out on the subject of the society in pre-Roman Dacia, this scientific work represents the first complex writing that makes major contributions to the historiography in the Romanian space.

Between 1987-1988 Ioan Glodariu, a renowned researcher of pre-Roman Dacia, publishes an article in which

\footnotetext{
7 LICA/GOSTAR 1984, 70-75

48 LICA/GOSTAR 1984, 63-65.

${ }^{49}$ LICA/ GOSTAR 1984, 104.
} 
he makes a strict analysis of what has been written before him about the Dacian society and how it was stratified. Like the historians of the previous historiographic periods and Glodariu, he comes to note the existence of two social blankets in the pre-Roman Dacia ${ }^{50}$.

For most of the modern researchers (Tocilescu, Pârvan, C. Daicoviciu, Gostar, H. Daicoviciu) the society of pre-Roman Dacia is structured in this way, but some special opinions were formulated by A. Bodor, who concludes, based on the text of Iordanes, that the indigenous society in Dacia was stratified into three distinct social groups: "those who were of the nation ... called tarabostes or pileati", "and the rest of the people ... capillati", in other words there was a secular aristocracy, a religious one and the common people ${ }^{51}$.

Glodariu considers that no such clear distinction can be made between secular and religious aristocracy, all the more so as the religious sect seems to be recruited from the ranks of the nobles. He also argues that it is possible that some of those who are part of the comati have reached higher positions, as suggested by the participation of several comati at a Dacian council and the message formed by the comati sent to Emperor Trajan. The archaeological discoveries reflect the existence and the accentuation of the differentiations within the Geto-Dacian society, in this sense we mention the modest and luxurious dwellings, the latter being grouped in the fortified area of the settlements and in the aristocratic "neighborhood" of Sarmizegetusa ${ }^{52}$.

Regarding the role of slaves in the production of pre-Roman Dacia, Glodariu has the same opinion as his forerunners, not assigning an important role to the slaves, but to the free people who are the main producers. The historian states that what we know with certainty about a certain society cannot be taken over and put on the account of another society that is on "similar" stages of evolution: first, because it is methodologically wrong, and secondly in the absence of any evidence to suggest it, it is not credible, therefore the comparative method must be used with discernment and with great caution. The lines of I. Glodariu constitute the clearest and best argued rejection of the exaggerations operated until then.

\section{THE CLIMATE OF FREEDOM AFTER 1989}

The collapse of communism in 1989 opened a new page in Romanian historiography, and the regaining of freedom of expression had an immediate impact on history, drawing new evolutionary lines and initiating new research aimed at instilling a new scientific spirit.

The historiographic production outlined after the collapse of the communist regime confirms an advance of the frontier of knowledge through real research, but in the Romanian historiographic field, many authors who are outside the professionalism appear.

Post-December historiography is best connected with historiography and research published in the Western European space, and as a result Romanian researchers are beginning to present a critical spirit to their own work. They become aware of the spatial and temporal archaeological

\footnotetext{
${ }^{50}$ GLODARIU 1987-1988, 538.

${ }^{51}$ BODOR 1981, 12.

52 GLODARIU 1987 - 1988, 539.
}

boundaries, and in the crystallization of opinions regarding a territory or the population that lived in that space, they do not rush to generalize and attribute the existing knowledge regarding a certain society to another society that presents a certain similar aspect.

In 1993, Ion Horațiu Crișan writes a new paper that talks about the indigenous society in Dacia and how it was stratified. As a working method in trying to "define" the Dacian society, it uses the analysis of literary sources and archaeological sources, finding that it is divided into two categories, those already mentioned during the research. Note that the aristocracy included the military chiefs, tribesmen, and among the nobles the clergy were chosen. He considers that in the Dacian society the priests played an important role, a hypothesis formulated on analogies with the Celts, Iranians and Aryans.

The literary sources record the importance held by the priestly elemental in the Dacian life, in the pre-Roman Dacia the supreme leadership was exercised by the king and the high priest, a phenomenon often encountered in the ancient world. According to Iordanes, Deceneu undertook a religious reform. Crișan considers that he had more quickly achieved a stratification of the priesthood, so that the peaks of the priesthood consisted of pileati and its mass of capillati. As a result of this interpretation of Iordanes' text, the historian states that those who call themselves capillati are not the ordinary people, but a privileged class. In support of his interpretations come the notes made by Dio Cassius regarding the message sent by Decebal to Emperor Trajan ${ }^{53}$. We find that I. Crișan retains his views even under the new historiographical conditions.

In 1997, the university professor Gelu Florea together with the renowned archaeologist Valeriu Sîrbu wrote a paper that addresses from a new perspective problem that have been studied and analyzed over time by historians. The topics covered include the way in which the Dacian society is stabilized and divided into social classes. The authors note that the written information referring to Dacia and to the society present during the kingdom if they multiply as the territory of Dacia comes under the ruling of the Romans. Consequently, the ancients transmit to posterity the names of those who formed the Dacian social classes: taraboste/ pileati and comati/capillati.

Numerous historians have analyzed the meaning of these terms (for example I. I. Russu translates the term tarabostes as "too bright"), Gelu Florea concludes that the Dacian-Gothic aristocracy from the period of the Dacian kingdom already had a brilliant tradition behind it, being a tribal one, whose main occupation was war. As evidence of the assumptions raised by the historian of Cluj, the fortified sites and the inventories of tombs that have been discovered in different archaeological sites are highlighted: Popești, Cugir, Brad ${ }^{54}$.

This warrior nobility, regimented under the command of Burebista, most likely contributed to the campaigns to extend Dacian power and influence in Europe. Following the archaeological discoveries, accidental or systematically and scientifically made, carried out in the great fortified

\footnotetext{
${ }^{3}$ CRIȘAN 1993, 90-91

${ }^{54}$ FLOREA 1997, 17.
} 
settlements or in the Dacian fortresses, luxury objects and import objects (ceramic, bronze or silver dishes, opaques, amphorae have emerged; they were used as containers for wine and oil) - objects that talk about the well-being and tastes of those who lived on the Acropolis.

In another paper, historian Gelu Florea talks about the painted Dacian pottery and its importance in the society of pre-Roman Dacia, concluding that the pottery discovered in the Orăștiei Mountains is a special pottery, which no longer appears elsewhere on the territory of Dacia, probably due to the fact that it is a luxury ceramic. Within the Dacian pottery there is the pottery painted with zoomorphic and vegetal motifs, which was discoveredmostly in the Dacian complex in the Orăștiei Mountains, the historian considering that this is a courtyard pottery, a luxury pottery, belonging to the local aristocracy ${ }^{55}$.

As a result of the archaeological investigations that were carried out in the Dacian fortresses, tower-dwellings (Costești, Blidaru, Căpâlna, Tilișca) were revealed, thus demonstrating the existence of military commanders who most likely belonged to the nobility, and the rich inventory discovered in the cities such as Piatra Roșie or Piatra Craivii attests to the wealth and luxury that they were surrounded by.

The quoted author remembers comati/capillati and considers them to be the mass of ordinary people and is of the opinion that they represented the majority who lived in open Dacian settlements. Ion Horațiu Crișan draws a parallel between the category of the counties of Dacia and the knights of Gallia, considering that these two social layers are similar. This analogy is based on the information obtained from the texts of Dio Cassius and Iordanes, but, although this analogy cannot be proved, Gelu Florea is of the opinion that it is not excluded that in the period of the Dacian kingdom there was an intermediate social class, and the difference should consist in the property held and not the social status ${ }^{56}$.

In 2001 the Romanian Academy publishes the first edition of the volume "History of Romanians", the part referring to the pre-Roman Dacia from this work belongs to Ioan Glodariu. The information presented in this paper generally belongs to the ' 80 s, so that the opinion outlined in this paper is at a lower stage than the researches and novelties brought by other historians (e.g. G. Florea, A. Rustoiu, V. Sirbu). Ioan Glodariu carries out an analysis of the ancient texts, deducing that within the society of Dacia two social categories are outlined, those mentioned above. We deduce that the aristocracy differed from the mass of the people by the fact that it wore that pileus, which was a distinguishing sign.

According to Iordanes, the historian considers that in the Geto-Dacians three social layers were distinguished: a secular aristocracy, a religious aristocracy and the common people, but this opinion cannot be sustained, due to the fact that within the aristocracy there is no distinction between the secular and the religious, especially since the priests seems to be recruited from the ranks of the nobles. Regarding the opinions according to which the capillati/comati would be situated between the aristocracy and the common people, either as an intermediate blanket or as knights, the cited author

$\overline{{ }_{55} \text { FLOREA 1998, 60-65. }}$.

${ }^{56}$ FLOREA 1997, 18. considers that these are speculations or the transposition of a known situation from the Celtic world to the Dacian one.

The archaeological discoveries bring to light differentiation of wealth, but not always social, so that we can analyze modest and luxurious houses - the latter being grouped in the fortified area of settlements and in the aristocratic neighborhood of Sarmizegetusa, there are also monetary treasures and ornaments.

Ioan Glodariu mentions here the attributions and the role that the clergy played in the social organization of the Dacian period. Based on the text of Iordanes, the quoted author thinks that the high priest Deceneu undertook a priestly reform, which should not be understood in the sense of hierarchy of divinities, but rather as an institutional organization of religion, as an arrangement of the activity of the worshipers with the interests of royalty, thus achieving a hierarchy within the priesthood ${ }^{57}$.

In 2002 the historian and archaeologist Aurel Rustoiu published a work, written from a modern perspective of social history, in which there are some mentions regarding the Dacian tomb of Călan. Following the archaeological excavations carried out here and the interpretation of the archaeological material discovered, it was concluded that during the 1st century $\mathrm{BC}$ the tumulary tombs make their presence in the area of southwest Transylvania, in Muntenia and in Moldova, while in the 1st century of AD the presence of these tombs is reduced in the area of the Siret river.

Aurel Rustoiu also notes that the tumular necropolises of Dacia are not too large, and after more detailed investigations it was concluded that these tumular necropolises could represent family necropolises, belonging to the Dacian aristocracy, the majority being within the fortified settlements ${ }^{58}$.

Mrs. Zoe Petre publishes in 2004 a paper that analyzes the Greek literary sources that refer to the Dacians. Within this analysis the subject of the Dacian society is also framed and a way in which it was structured, bringing into discussion old research topics, which are exposed in a new light. In this paper, Mrs. Zoe Petre resumes the discussions regarding the Dacians carrying the cap (pileati) and the shaggy Dacian (comati), and the opinions highlighted in this paper differ significantly from what was written previously. Referring to the groups of messagers of the comati/capillati sent by Decebal to Emperor Trajan, he thinks that they cannot represent the ordinary people, but would rather designate a warrior class, of commanders in Decebal's army. Later these comati are replaced by pilophoroi/pileati, who were representatives of a political and military authority, as well as beneficiaries of a sacred authority aura.

Zoe Petre considers that it is inadmissible for the platoon warriors to transform from a distinct and respected social category, which had an element of superiority, into a lower category. The author introduces a new dimension during Deceneu, the noble class being characterized by a double vocation, converting their activity from the military to the priestly one, and these changes led to the increase of the military role held by the comati, which were subordinate to the king ${ }^{59}$.

\footnotetext{
HISTORY OF ROMANIANS 2001, 823-835

${ }^{58}$ RUSTOIU 2002, 115-116.

${ }^{59}$ PETRE 2004, 250-257.
} 
Eugen Iaroslavschi publishes an article in 2006, in which he writes down the opinions regarding the society in Dacia, outlined over time by historians. He considers that the problem of social stratification has been a concern for historians, even though not all have insisted on details of a literary or archaeological nature. Over time, the number of ancient sources remained unchanged, but the number of archaeological discoveries made in Dacian settlements and fortresses increased; the distinguishing element is how these archaeological discoveries were interpreted by historians. The mentioned author thinks that, if in 1926 Vasile Pârvan had benefited from several archaeological digs, no doubt the Dacian society would no longer be characterized as belonging to the "wood culture", but even so he considered that the Dacian-gothic society is divided into nobles and ordinary people.

Iaroslavschi recalls the fact that in 1960, Constantin Daicoviciu, included in the social category of the comati the landless peasants, agricultural workers, shepherds and craftsmen who were in a state of dependence on the nobility ${ }^{60}$. He notes that A. Bodor believes that the presence of merchants and craftsmen is emphasized within the shaggy Dacians ${ }^{61}$, thus sharing the same opinion as Hadrian Daicoviciu $^{62}$. The historian Ion Horațiu Crișan is of another opinion, he makes a comparison between the Celts and the Dacians, resembling the noble class from the Dacians, the pileati, with the great Celtic nobility, and on the comati with equites - the Celtic knights ${ }^{63}$.

Iaroslavschi notes that A. Bodor shares the same opinion as the two historians Daicoviciu, who believes that within the social blanket of the comati there should be included traders, shepherds, agricultural workers, craftsmen, but in contrast to them Bodor thinks that within this category rich peasants can also be incorporated.

Iaroslavschi notes that, excepting M. Macrea, who did not agree with the conception that the Dacian state was a slave state, all historians who wrote before 1989 considered that the Geto-Dacian society was divided into antagonistic classes $^{64}$.

The archaeological researches came to complement the information transmitted by the ancients, the most significant data provided by the archaeologists were obtained from the capital area, so, here were identified many tools that belonged to the craftsmen: ovens, traces of workshops and suggestive artifacts for practicing many crafts. As a result of the archaeological excavations, the researchers observed that at the foot of Muncelului Hill there are smaller terraces, which include modest dwellings in size and inventory, and as we move towards the top of the hill the terraces widen as dimensions, having more complicated housing plans and the inventory of these houses speaks of the well-being of the inhabitants. The author is quoted on the opinion that we are dealing with a "vertical" stratification of the inhabitants and that at the top of the dwelling were the richest, especially the secular and religious nobility.

\footnotetext{
${ }^{60}$ DAICOVICIU 1960, 280-285

${ }^{61}$ BODOR 1981, 8.

${ }^{62}$ DAICOVICIU 1972, 18

${ }^{63}$ CRIȘAN 1977, 199-200.

${ }^{64}$ IAROSLAVSCHI 2006, 260.
}

The scholar notes that most of the iron tools (hammers, anvils) were buried on the upper terraces, considering that those who used these iron tools had their workshops or housing on the terraces near the top of the hill. These findings lead him to believe that the craft of metalworking was developed, as metallurgists were enjoying a good economic situation. He notes that the tarabostes/ pileati represented the dominant class, while the ordinary people/capillati/comati formed the submissive class, with the possibility that some of the people who made up the mass of the population would enter theranks of the nobles, due to their economic power. It is believed that theDacian metallurgists in the urban settlement, Sarmizegetusa, fall among these comati with the privileged state ${ }^{65}$.I

In 2006, university professor Gelu Florea publishes a new paper in English that deals with the subject of the Dacian society during the period of royalty. He notes that the historical researches of the last decades have been influenced by the communist doctrine and that some historians have reluctantly looked at the theoretical works proposed by anthropology, sociology and economy, so that the topics specific to social history, which deal with problems such as the organization of society, are practically non-existent in many publications or in scientific meetings.

The ancient texts speak of a structuring of the Dacian society in two social layers, and following the interpretation of these texts, the historians have agreed on two things: the Dacian society is structured into nobles/pilates/tarabostes and ordinary people/comati/capillati, admitting the existence of a symbol, pileus, which demonstrates the belonging to the noble status. The other approach refers to the capillati/ comati,they are mentioned in the texts as members of an intermediate status of the aristocracy and ordinary people.

The historian notes in his work the opinions of author Zoe Petre, who reopened the problem of the intermediate social status of this category - which contains professional warriors and free owners. For the period of Burebista, the society was dominated by the high aristocracy/pileati, having a double qualification, military and priestly. The paper notes that a non-conformist view with the notions imposed by the communist doctrine is that of Hadrian Daicoviciu, who considers that the ancient texts refer to the social status, that of noble or ignoble and not to social classes, so that a comatus could hold an important status in the society or at the king's court, due to his wealth or qualities.

Gelu Florea is of the opinion that the source of authority, power was never being born, you did not hold high functions only if you were born in a certain social category, this becoming very unlikely in a society with a strong military character, which has experienced moments of expansion and institutionalization. It is of the opinion that in the concept of "elite" it should be reflected more than a traditional aristocracy, at the same time the possibility of the overlap between hereditary nobility and belonging to the nobility by personal merits should be considered. The professor is of the opinion that access to a high status could also be obtained through personal values, through services provided to the ruling power, or by demonstrating courage on the battlefield.

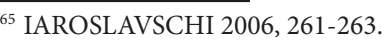


The written sources offer very little information in this regard, but there is a unanimously accepted opinion, namely that of "vertical mobility" (this vertical mobility assumes that society manifests a certain availability and capacity to receive and integrate new members into the elite) within the framework of the higher categories of the Dacian aristocracy. Another debated topic is the creation of elites with origins other than those with noble blood, being imposed locally or around the power centers, especially during Decebal's reign ${ }^{66}$.

The renowned archaeologist Valeriu Sîrbu publishes in 2006 a work focusing on the spiritual research of the northDanube Thracians, the opinions expressed in this work are based on a series of archaeological excavations carried out throughout the country, as well as in the neighboring spaces. He considers that for the period of the 1st centuries $B C$ and $\mathrm{AD}$ the hierarchies of the Dacian state concentrated around the king, part of the aristocracy existing in this territory turned into a court aristocracy that received military, political and priestly ranks.

The ancient sources record the name of this social class existing in the royal Dacia, tarabostes and pileate within which were appointed representatives for the following functions: viceroys and agricultural administrators. The archaeologist believes that, because the king no longer tolerated the centrifugal tendencies, when he benefited from the necessary means he imposed his authority, thus all the power concentrating around the king.

The work contains references to the priestly power, the historian considering that the clergy were organized hierarchically and was the depositary of a corpus of knowledge about the universe and deities, about life and death $^{67}$.

In 2010 the Romanian Academy publishes the second edition of the paper entitled "The History of Romanians", the observations regarding the Dacian society are also made by Glodariu, as in the case of the 2001 edition. The subject of the Dacian society does not change significantly, the same opinions being stated ${ }^{68}$.

These are the contemporary opinions referring to the Dacian society from the period of the Geto-Dacian kingdom, opinions that were formed as a result of studying the literary sources and the archaeological material collected from all over the country, especially from the Dacian complex in the Orăștiei Mountains, and also the correlation of historical writing with historiography and specialized research existing in the European space.

\section{CONCLUSIONS}

The present paper aims to reconstruct and follow the itinerary of Romanian historiography targeting the Dacian society from the Dacian royal period. The evolutionary direction of the opinions regarding the indigenous society in Dacia and its stratification was followed.

During the research, it is noted that the concepts and the historical writing were determined by the structure of the present, thus we identify six periods that differ due

\footnotetext{
${ }^{66}$ FLOREA 2006, 2-4.

${ }^{67}$ SÎRBU 2006, 162-163.

${ }^{68}$ HISTORY OF ROMANIANS 2010, 823-825.
}

to the political factor that requires a specific approach to the promoted doctrine. The starting point in the study of historiography is the beginning period, the end of the nineteenth century, when historians begin to write a scientific history, giving up romantic conceptions.

During this period and until the end of the First World War, historians carry out titanic work, which aimed to gather all the information concerning the Geto-Dacian civilization. The subject of the Geto-Dacian society is treated in a fugitive way, noting the idea that in Dacia, within the time span between Burebista and Decebal's reign, there was a society that was divided into two social classes: in nobles/ pileati and in ordinary people/comati.

In the interwar period, the same information is known regarding the subject of our research, based only on the literary sources, previously used, in order to carry out a more complex study, the historians also refer to the interpretation of the major artistic monuments known, as referential research objects(Trajan's Column and Adamclissi monument). The archaeological excavations, still very limited, do not contribute to the change of the vision on the Dacian society.

With the establishment of the communist regime, the historians' opinions become features of the ideological patterns of the communist doctrine that have been manifesting since 1948. Starting with the ' 50 s of the last century, the archaeological excavations of Grădiștea Muncelului, under Constantin Daicoviciu leadership, have been enlarged and regularized.

During the Stalinist period (1948-1960) the outlined opinion referring to the indigenous society in pre-Roman Dacia is formulated by Constantin Daicoviciu, who perceives this society as an early slave based, military type, in which slavery played a major role in production of economic goods. Moreover, the communist-stalinist ideology, dictated by the Moscow dogmas, regards the Dacian state as a slave state.

Starting with 1960 in Romania, communist perceptions gradually flip 180 degrees, establishing a period of return to national values. Now the role played by slaves in society is no longer exaggerated, but according to literary sources and archaeological research it is considered that they did not play an important role, the main role in the economy being held by free / ignoble people, who were enslaved in one or more ways by nobility.

In the time period between 1960-1975 the communist ideology no longer looked at the Dacian society, especially from the perspective of the "class struggle". It is the period when more nuanced opinions are affirmed about the society in pre-Roman Dacia, but without leaving the marxist model of interpretation.

In the historiographic period known as the communist-nationalist period (1975-1989) an exaggeration of the Dacian element is observed at the expense of the Latin element, which is denied. In this period the Ceausist ideology is affirmed, which promotes concepts such as the multimillennial existence and the Dacian monolithic unit; seen as a foreshadowing of the Romanian state formation and at the same time of the authoritarian and isolationist policy of the regime. In this period, as in the previous one, there is talk of splitting the Dacian society into two social 
categories: the pileati that represented the aristocracy and the comati being the ordinary people, but the tendency to see the second social category as an second rank elite is also pointed out.

The appearance of social conditions was increasingly left behind. It points to the existence of a clergy, which was organized hierarchically, the high priest also having the function of viceroy, and based on the ancient texts, there is talk about the existence of slaves and freedmen. It is interesting to note that the opinions agreed by the political power combined two contradictory elements: on the one hand, the analogies with the Celtic world were being abused, on the other, the unique and unitary character of the Dacian civilization and society was exaggerated.

In fact, it can be said that throughout the existence of the communist regime in the interpretation of the indigenous society it did not go beyond the simple social stratification in elites and people. The progress made had to manifest itself in an ideological system full of constraints, and the achievements of modern sociology or western anthropology were completely ignored.

The most representative period for our research is illustrated by contemporaneity, which is asserted in the historiographic framework since December 1989, when the communist regime collapses. This historical moment represents the beginning of a period of freedom in asserting the opinions regarding the Dacian society, and the historical writing obliterates the ideologies and visions imposed by the party. The historians who deal with the subject of the Dacian society are oriented and take as their model the writings and the specialized literature existing in the Western-European space.

In shaping the opinions of contemporary specialists, they show a higher critical spirit, even compared to their own works. As in previous historiographical periods, there is talk in the specialized literature about the existence of two social blankets, but one opinion that is not found in the old writings is that of Gelu Florea, who considers that during the Dacian period, the honorability and the noble status are not necessarily given by birth, but can be acquired through personal efforts. The historian observes after field research that the Dacian aristocracy was a court, for which the rank was established by the function in the state, reaching this conclusion after researching and studying the dwelling towers that are located in the Dacian complex in the Orăștiei Mountains.

He studies the ceramics of Dacian manufacture in the capital of the pre-Roman Dacia and finds that part of the decorated ceramics, the ones with zoomorphic and vegetal motifs, are found only in the Orăștiei area, illustrating a courtyard pottery, destined for the local aristocracy. Quite remarkable and innovative are the efforts of the new generation of researchers (V. Sîrbu, G. Florea, A. Rustoiu) to archeologically capture the social elites of the pre-Roman Dacia and their position regarding political power.

After reviewing the historiographical periods in which the Dacian society is defined differently, depending on the wishes of the ruling party or the interpretation capabilities of the specialist, we can say that past and present research is not sufficient to know the Dacian society in detail. Not all the gaps in history related to the subject have been covered yet, but we know some general data describing the societies in the European space, which despite the fact that they capture common coordinates, however, they cannot be attributed to another society, even if it is related to it and is in similar developmental stages. The few literary sources that refer to the Dacian society have been analyzed, therefore there are minimal chances for them to make valuable contributions in the future. In contrast, archeology always brings additional contributions, the interpretation of which requires the use of written sources and a large specialized culture. So the debate remains open.

\section{REFERENCES}

\section{ALFÖLDY 1988}

Alföldy, G., Social History of Rome (Baltimore:The Johns Hopkins University Press).

ANTONESCU 1889

Antonescu, T., Cultul cabirilor în Dacia (București: A. Degenmann).

BABEȘ 1974

Babeș, M., Puncte de vedere relative la o istorie a Daciei preromane, Studii și Cercetări de Istorie Veche 25/2, 220-24.

BERCIU 1980

Berciu, D., Burebista și tradiția statală, Revista de Istorie 33/6, 138-139.

\section{BODOR 1981}

Bodor, A., Structura societății dacice. In: Daicoviciu, H (ed.), Studii Dacice (Cluj: Dacia), 7-21.

\section{CRIȘAN 1977}

Crișan I., H., Burebista și epoca sa (București: Editura Științifică și Enciclopedică).

\section{CRIȘAN 1993}

Crișan, I.,H., Civilizația geto-dacilor. vol.1 (București: Meridiane).

\section{DAICOVICIU 1945}

Daicoviciu, C., La Transylvanie dans l'antiquité, (București).

\section{DAICOVICIU 1950}

Daicoviciu, C., Dacii din munții Orăștiei și începutul statului sclavagist dac, Studii și Cercetări Știiințifice1 (Cluj), 111-126.

\section{DAICOVICIU 1950}

Daicoviciu, C., Studiul traiului dacilor din munții Orăștiei, Studii și Cercetări de Istorie Veche1/1, 270-281.

DAICOVICIU 1960

Daicoviciu, C., Statul dac de la Burebista la Decebal.In: Istoria României1 (București: Editura Acadenmiei), 280283.

DAICOVICIU 1965

Daicoviciu, H., Dacii (București: Editura Științifică).

DAICOVICIU C./DAICOVICIU H. 1969

Daicoviciu, C./Daicoviciu, H., Istoria României, compendiu (București: Editura Didactică și Pedagogică), 42-43.

DAICOVICIU 1972

Daicoviciu, H., Dacii (București: Editura Enciclopedică Română).

DAICOVICIU 1972

Daicoviciu, H., Dacia de la Burebista la cucerirea romană (Cluj: Dacia).

FLOREA 1997

Florea, G., Imagine și imaginar în Dacia preromană (Brăila: Istros), 17-18.

\section{FLOREA 1998}

Florea, G., Ceramica pictată. Artă, meșteșug și societate în Dacia preromană (Cluj-Napoca: Presa Universitară Clujeană). 


\section{FLOREA 2006}

Florea, G., The "Public Image" of the Dacian Aristocracy, Studia Universitatis Babeș-Bolyai. Historia 51/1, 1-11.

\section{GIURESCU 1946}

Giurescu, C.C., Istoria Românilor (București: Editura Fundației pentru Literatură și Artă).

GLODARIU 1987-1988

Glodariu, I., Opinii privitoare la stratificarea societății dacice, Acta Museis Napocensis 24-25, 537-543.

GLODARIU 2001

Glodariu, I., Structura socială. In: Istoria Românilor (București: Editura Enciclopedică), 762-776.

GLODARIU 2010

Glodariu, I., Structura socială. In Istoria Românilor (Bucuresti: Editura Enciclopedică), 823-825.

IAROSLAVSCHI 2006

Iaroslavschi, E., Statutul social al metalurgiștilor daci. In: Gaiu, C./Găzdac, C: Fontes Historiae. Studia in honorem Demetrii Protase (Cluj-Napoca: Accent), 258-261.

IORGA 1922

Iorga, N., Istoria poporului românesc, vol.I (București: Editura

IORGA 1936 Casei Școalelor).

Iorga, N., Istoria românilor I (București).

KRAMER 1962

Kramer, S., N., Istoria începe la Sumer (București: Editura Stiințifică).

LICA/GOSTAR 1984

Lica, V./Gostar, N., Societatea daco-getică de la Burebista la Decebal (Iasi: Junimea).

MACREA 1954

Macrea, M., Procesul separării orașului de sat la daci. In: Studii și referate privind istoria României I (București: Editura Academiei Române), 119-146.

NISTOR/VALEA 1977

Nistor, A./Valea, M., Succinte considerații privind diferențierea socială în perioada Burebista - Decebal, Sargetia. Acta Musei Devensis 11-13, 35-36.

\section{PÂRVAN 1926}

Pârvan, V., Getica. O protoistorie a Daciei (București: Cultura Națională).

\section{PETRE 2004}

Petre, Z., Practica nemuririi. O lectură critică a izvoarelor grecești referitoare la geți (Iași: Polirom).

\section{PIPPIDI 1967}

Pippidi, D.M., Contribuții la istoria veche a României (București: Editura Științifică).

\section{ROLLER 1948}

Roller, M., Istoria R.P.R. Manual pentru învățământul mediu (București: Editura Didactică și Pedagogică).

\section{RUSSU 1967}

Russu, I.I., Limba traco-dacilor (București: Editura Științifică).

\section{RUSTOIU 2002}

Rustoiu, A., Războinici și artizani de prestigiu în Dacia preromană (Cluj-Napoca: Nereamia Napocae).

\section{SÎRBU 2006}

Sîrbu, V., Oameni și zei în lumea daco-getă. Mărturii arheologice (Brașov: Editura C2 Design).

\section{TEODOR 2002}

Teodor, P., Introducere în istoria istoriografiei din România (Cluj-Napoca: Accent).

\section{TOCILESCU 1885}

Tocilescu,G., Dacia înainte de romani. Cercetari asupra poporeloru carii au locuitu tierile romane de a stang'a Dunarii, mai inainte de concuista acestoru tieri de cotra imperatoriulu Traianu (București: Tipografia Academiei Române).

\section{XENOPOL 1985}

Xenopol, A.D., Istoria Românilor din Dacia Traiană (București: Editura Ştiinţifică Enciclopedică). 